\title{
Loan Loss Provisioning Based on Cyclicality
}

\author{
Ning yuxin ${ }^{1}$, a* Wang huanyin ${ }^{2, b}$ \\ ${ }^{1}$ Economics and Management school, Xi'an Shiyou University, Shanxi, Xi'an 710065 \\ ${ }^{2}$ Economics and Management school, Xi'an Shiyou University, Shanxi, Xi'an 710065 \\ anyx91@sina.com, b2859293613@qq.com
}

\begin{abstract}
We make use of the listed commercial banks' 2004-2012 half-yearly panel data to test cyclical effects of loan loss provisioning. By GMM estimating some factors which influence loan loss provisioning, we find that our commercial banks loan have countercyclical effect owing to the existence of discretionary loan loss provisions. At the meantime, commercial banks have motivations to manage earnings.
\end{abstract}

Keywords: cyclicality ; earning management; capital supervision ; discretionary loan loss

provisions

\section{Introduction}

Loan loss provisions(LLPs) plays an important role in the credit risk management of the bank. LLPs are expected to reflect anticipated loss by bank managers and avoid the huge impact which economic downturn may bring to the bank, LLPs are treated as " cushions " to protect the bank 's own capital. However, due to financial innovation and the popularity of asset securitization, a lot of risk assets are transferred out as off-balance-sheet items. Meanwhile, many banks often relax lending standards, increase credit supply and underestimate the expected loan losses during the booming years. During recession time, it is difficult to cover the estimated loan losses, so the banks have to write off capital to compensate for the loss and be forced to cut large scale loan to meet the requirements of capital adequacy regulation policy at the same time which may cause further decline in the economy. Therefore, many national regulators think that LLPs' pro-cyclical effect becomes an "internal accelerator " of credit cyclical fluctuations. For this reason, the reform of bank loan provisioning system and the implementation of forward looking provisioning system has become an important topic of the financial regulatory authorities after 2007 financial crisis era.

However, we should note that bank's loan loss provisioning behavior is determined by past loan loss provisioning experience, non-performing assets rate and expected loan risk etc. Secondly, the size of loans and loan growth rate are important indicators to predict future risk of bank. Except for these factors, it is necessary for many banks to satisfy supervision capital adequacy rate and performance evaluation requirements when drawing LLPs. In order to meet regulatory capital adequacy requirements during the economic downturn, the bank would tighten credit supply and strengthen the pro-cyclical effect of loan loss reserve provisioning. On the other hand, the bank will use the loan loss provisioning to manage earnings. Bank managers often use LLPs as a tool to reduce volatility of earnings resulted from economy cycles. In conclusions, forward looking provisioning system may cause the prevalence of earning management behavior which would be not conducive to the implementation of capital regulatory policies, as well as lead to " counter-cyclical " effect of loan loss provisioning.

For above the reasons, this paper divides LLPs into non-discretionary loan loss provisioning (non-discretionary LLP, abbreviated NDLLP) and discretionary loan loss provisioning (discretionary LLP, abbreviated DLLP). Based on the semi-annual panel data from 2004 to 2012 of the listed banks, the paper utilizes GMM to estimate some factors which may affect loan loss provisioning. 
The paper confirms that NDLLP has no significant influence on bank credit, DLLP has a significant positive effect on bank credits, which indicates that excessive DLLP provisioning will promote the growth of credit scale. Secondly, due to the necessity of discretionary loan loss provisioning, the bank also has the motivation for earnings management in order to meet the need of performance appraisal. The empirical tests provide relevant evidences that how some factors for loan loss provisioning are interactive. The paper provides necessary theoretical foundation for the LLPs' policy choice

The remainder of this paper is organized as follows. In section 1, we briefly review previous papers . Section 2 is about literature review. Section 3 is theoretical analysis and research hypothesis. Section 4 is empirical research design. and empirical results in section 5. Section 6 discusses the main findings and conclusions.

\section{Literature review}

\subsection{The target and foundation of loan loss provisioning}

LLPs are expected to cover future losses of banks. According to 2002 " New Basel Capital Accord " the core capital only includes paid-up capital, capital reserves and other owners' equity capital .Loan loss reserves which occurred more than expected would be allowed to enter the subsidiary capital with limitation. Maximum of which are no more than $1.25 \%$ of risk-weighted assets (Lu Jun and Li Yujia, 2006). The amount of loan loss provisioning depends on the correct estimation of future expected losses. High LLPs would affect the profit of banks and reduce the capital amount which couldn't meet the capital adequacy standards of regulatory authority; Low loan loss reserve cannot resist the huge impacts of the financial crisis and lead to the bankruptcy liquidation of banks in financial "tsunami" inevitably. Secondly, banks as modern enterprises endogenously have agency problems which arise from the separation of ownership and management. In practice, loan loss reserves are balance between different factors such as future anticipated losses, regulatory capital requirements and earnings management. Anwer S. Ahmed and Carolyn Takeda (1999) made a research about loan loss provisioning of US commercial banks from 1986-1995 which showed that capital supervision is the primary factor considered when drawing LLPs. There is a significant negative correlation between loan loss reserves and core capitals for those enterprises which have a high loan growth rate. However, the study did not find a significant relationship between loan loss reserves and earnings management. Michele Cavallo and Giovanni Majnoni (2001) analyzed the loan loss provisioning of 1176 commercial banks from 1988-1999 and found that there is a significant positive correlation between loan loss reserves and bank's EBIT in G10 countries' banks which has not been confirmed in non-G10 countries' commercial banks. Non-G10 countries' banks create little provisions in good times and are forced to increase them during economic downturn. The study also found that there is a significant negative correlation between bank profits and loan losses provisioning for those banks with "external" guarantees. According to the above researches, we could have some conclusions that for those companies that have good performance earning management is the main factor which mangers consider to create loan loss reserves. On the other hand for those companies with poor performance or high credit risk, capital regulatory requirements and safeguarding credit risk are the main factors to be considered. Duan Junshan (2012) found that loan loss provisions are positive with total loans, ROE, non-performing rate and money supply which indicated the possibility of earnings management when LLPs are drawn in China.

\subsection{Loan loss provisioning and Credit Cycle}

Macro-economic are cyclically fluctuating and the interaction between the financial system and macroeconomic activities makes commercial bank credit not only having the cyclical features ,but also have the effects of “acceleration amplification”. Antonio Garcia Pascual (2009) have studied on the financial systems of 11 East Asian countries and showed that the variation of collateral value , strict capital supervision, large number of relationship lending, insufficiency of LLPs and so on led credit system play an important role as financial accelerator. C\&M, L\&M and Bikker and Hu (2002) found that during economy flourishing credit supply grow fastly and bank's manager would draw 
lower LLPs based on higher asset prices and good expected performance compared to economic downturn. LLPs did not only " ironing" the impact of economic fluctuation but also accelerate economic downturn. Corporate bankruptcies would increase bad debts and bank's managers have to write off large amount of loan loss reserves which led the rapid decline of bank performance during the economic downturn. Therefore, loan loss provisioning is regarded as "push culprit " of further economic slowdown. Borio et al (2001) and Lowe (2002) thought that there should be a positive relationship between LLPs and credit scale. That is under good performance, banks should draw more LLPs to avoid credit losses occurring during the economic downturn .JA Bikker and PAJ Metzemakers (2002) made a analysis on bank data of 29 OECD countries during past 10 years and found that the ratio of loan loss provisioning improved significantly when the GDP growth rate is low, which can support the " pro-cyclical " effect of loan losses provisioning. They also found that if bank increased LLPs as the performance improved, which would weaken the pro-cyclical effect of loan losses provisioning. This results are different from those of Cavallo and Majnoni (2002). They found that there were a significant inverse relationship between credit growth and loan loss provisioning. Scott Liao (2009) found that the credit reduced amounts of banks based on the incurred model for LLPs is obviously higher than those of based on forward-looking banks in the economic recession, which can prove the " real-time " of loan loss provisioning can weaken the impact of the credit crunch. Eric Wong, Tom Fong and Henry Choi (2009) made a study on loan loss "pro-cyclical" effect of twelve listed banks in Hong Kong, which could prove the existence of the loan loss "pro-cyclical" effects and the impact on the supply of credit. Most studies support the idea of loan loss provisioning" pro-cyclical" effects, but why LLPs have pro-cyclical effects is still a controversial issue. The reason is due to the inadequacy of loan loss provisioning or meeting regulatory capital requirements. Secondly, how would earnings management make a reverse effect on loan losses "pro-cyclical "? The answers to these questions still need to be further studied.

\section{Loan loss provisioning and theoretical hypothesis in China}

China had experienced market-oriented reform for more than ten years. Loan loss provisioning was originally implemented according to the requirements of administrative orders. Ministry of Finance in July 1998 had promulgated the notice about how to draw the allowance for doubtful accounts. According to the notice, banks in China drew allowance for doubtful accounts regarding as $1 \%$ of the loan balanced per year which had deducted loan loss allowance of the previous year.

In April 2002, China People Bank promulgated "Bank Loan Loss Provisioning Guidelines “ which kept pace with international standards gradually. The Guidelines made definitions for general allowance, special allowance and specific allowance according to five categories of bank loans loss provisioning. Sun Tianqi and Yang Lan(2005) made a survey about LLPs for Chinese commercial Banks. They found that most banks' LLPs didn't show the pro-cyclical features. Xu Youchuan's (2011) research indicated that banks in China tend to evaluate their expected loss of credit portfolio according to incurred information and LLPs presented counter-cyclical feature, which indicated that banks would overestimate the expected loss of credit portfolio in good times and cut credit supply during recession time.

Beatty and Liao (2011) analyzed the motivations and consequences of loan loss provisioning from the viewpoint of timeliness. The so-called "timeliness"referred to the reaction prior to the credit system. The study of Beatty and Liao (2011) showed that the higher timeliness the bank was, the less significant credit periodicity it would be. Generally speaking, the timelier loan loss provisioning the bank is, the relatively higher provisioning ratio of discretionary loan loss provisioning it will be. Empirical analysis of Vincent, BOUVATIER Laetitia LEPETIT (2006) for 186 EU banks panel data from 1992-2004 had confirmed that non-discretionary LLPs had significant cyclical characteristics. Although Beatty and Liao (2011), Vincent BOUVATIER Laetitia LEPETIT (2006) made different categories for LLPs according to different rules. They all thought that LLPs shouldn't be simply regarded as being pro-cyclical or counter-cyclical, which should be considered by connecting with bank's own characteristics. 
We divide LLPs into discretionary loan loss provisions (DLLP) and nondiscretionary loan loss provisions (NDLLP). The NDLLP is "rigid" and DLLP has a larger flexible space. Therefore, it is anticipated that DLLP is an important "tool" for bank managers to smooth profits and manage earnings. When banks have enough DLLP, which means banks draw more LLPs according to future possible loss, therefore banks have great motivation to supply more credit which would lead to "countercyclical" effect between LLPs and credit scale. DLLP and NDLLP both will affect the bank after-tax profits, and have a negative impact on the capital adequacy ratio at the same time. Based on the above analysis, we propose the following hypothesis:

hypothesis 1: There is a significant positive correlation between discretionary loan loss provisioning (DLLP) and credit supplies.

hypothesis 2: There is a significant positive correlation between discretionary loan loss provisioning (DLLP) and profits;

hypothesis 3: discretionary loan loss provisioning (DLLP) and non-discretionary loan loss provisioning (NDLLP) both have a significant negative correlation with capital adequacy ratio.

\section{Empirical design}

\subsection{Sample selection and data sources}

We use 16 listed commercial banks from 2004 to 2012 years ${ }^{1}$ as empirical samples. LLPs had been disclosed in semi-reports after 2004. Therefore we make 6 months as a research period. From 2004 to 2012, we could have 288 unbalanced panel data. The related financial data is from GAT. LLPs and LLAs are from the semi-annual and annual reports in the official website which made manually.

\subsection{Methodology}

According to the above analysis, we made reference the ideas of Beatty and Liao (2011), Vincent BOUVATIER Laetitia LEPETIT (2006) and set model as the following phases:

The First Stage:

Firstly we should test the stationary of panel data because our sample is 16 section and 18 year-period as a "square-shaped" panel. Secondly, we should determine to use fixed effects model , random effects model or dynamic panel model. Thirdly, we would set econometric model to estimating NDLLPs and DLLPs. According to the incurred LLPs model, we concluded that NDLLP is mainly connected with NPL rate(non-performance loan), the variation of NPL rate and the loan loss allowance balance. The model is listed as follows:

$$
L L P_{i, t}=\alpha_{0}+\alpha_{1} \text { NPLrate }_{i, t-1}+\alpha_{2} \Delta \text { NPLrate }_{i, t}+\alpha_{3} L L A_{i, t}+\varepsilon_{i, t}
$$

With unbiased expectations, Equation (1) estimated expected regression NDLLP $P_{i, t}$ as NDLLP. The difference between the actual $N_{D L L P}$, and expected $N D L L P_{i, t}$ should be regarded as $D L L P_{i, t}$, which is normally distributed disturbances.

The Second Stage:

Because LLPs has the endogenous relationship with credit scale, capital adequacy and earnings before interest, taxes and provisions for loan loss, we make reference Love and Zicchino (2002) panel autoregressive model (PVAR) to estimate the bi-directional shock effect among these variables. Panel VAR consists of three main parts: the first is GMM, which illustrates the regression relationship among variables; the second is the analysis of error term variance, which could explain the error term impact proportion of the related factors; the third is the impulse response graphs. Through the dynamic impact response graphs, we could observe the reaction of each variable to impulse (Duan Junshan, 2011). PVAR model is set as follows:

\footnotetext{
${ }^{1} 16$ listed commercial banks respectively is China Everbright Bank, the Bank of China, industrial and Commercial Bank of China, agricultural bank, industrial bank, China Construction Bank, CITIC Bank, Bank of communications, China Merchants Bank, development bank, Shanghai Pudong Development Bank, Nanjing bank, Beijing bank, Ningbo bank, Huaxia Bank and Minsheng bank.
} 


$$
y_{i, t}=\Gamma y_{i, t-p}+\omega_{i}+\gamma_{t}+\mu_{i, t}
$$

$y_{i, t}=\left\{L L P_{i, t}\right.$, Loanrate $_{i, t}$, Nebirate $_{i, t}$ Capitalrate $\left._{i, t}\right\}$, which is the variable vector based on panel data $4 * 1, p$ is the lag order in the $y_{i, t-p}, \Gamma$ is the $4 * 4$ coefficient matrix, $, \omega_{i}, \gamma_{t}$ is the individual effect vector and time effect vector of $4^{*} 1$ dimension respectively, reflecting the heterogeneity of individual sections and specific impulse varying with time. $\mu_{i, t}$ is a random perturbation vector for $4 * 1$.

\subsection{Definition of variables and descriptive analysis}

Table 1 Sample description $(2004-2012, \mathrm{~N}=16, \mathrm{~T}=20, \mathrm{NT}=288)$

\begin{tabular}{|c|c|c|c|c|c|c|c|}
\hline Variables & $\begin{array}{l}\text { Variable } \\
\text { meaning }\end{array}$ & Calculation method & Average & Median & $\begin{array}{l}\text { Standard } \\
\text { deviation }\end{array}$ & Maximum & Minimum \\
\hline NPLrate & $\begin{array}{l}\text { Non-performin } \\
\text { g loan rate of } \\
\text { assets }\end{array}$ & $\begin{array}{l}\text { Total non-performing assets of } \\
\text { listed banks announced divided } \\
\text { by the initial loan amount }\end{array}$ & 0.0548 & 0.0408 & 0.0429 & 0.2543 & 0.0074 \\
\hline$L L P$ & $\begin{array}{l}\text { Provisions for } \\
\text { loan losses }\end{array}$ & $\begin{array}{l}\text { Loan loss provisioning divided } \\
\text { by } \\
\text { the total initial loan }\end{array}$ & 0.0078 & 0.0068 & 0.0062 & 0.0817 & 0.0004 \\
\hline$L L A$ & $\begin{array}{l}\text { Amounts of } \\
\text { reserves }\end{array}$ & $\begin{array}{l}\text { loan loss reserve closing balance } \\
\text { divided by the initial loan } \\
\text { amount }\end{array}$ & 0.0256 & 0.0244 & 0.0082 & 0.0631 & 0.0031 \\
\hline Loanrate & Loan rate & $\begin{array}{l}\text { The proportion of each period } \\
\text { total loans divided by initial total } \\
\text { assets }\end{array}$ & 0.5407 & 0.5250 & 0.0873 & 0.8426 & 0.3648 \\
\hline Nebirate & $\begin{array}{l}\text { Net assets } \\
\text { profit rate }\end{array}$ & $\begin{array}{l}\text { Earnings before interest and tax } \\
\text { and profit before provision for } \\
\text { loan loss divided by net assets of } \\
\text { listed banks }\end{array}$ & 0.3131 & 0.2994 & 0.1157 & 0.7279 & -0.1688 \\
\hline Capitalrate & $\begin{array}{l}\text { Capital } \\
\text { adequacy rate }\end{array}$ & $\begin{array}{l}\text { Tier one capital adequacy rate } \\
\text { index of listed banks reported }\end{array}$ & 0.1117 & 0.1134 & 0.0279 & 0.2100 & -0.0147 \\
\hline
\end{tabular}

Table 1 shows the descriptive statistics analysis of variables. The average non-performing loan of assets (NPLrate) accounted for the initial total loans is $5.48 \%$, and the median of which is $4.08 \%$. LLPs accounted for the initial loans is $0.78 \%$, the median of which is $0.68 \%$. The average loan scale accounted for total bank assets (Loanrate) is $54.07 \%$, with a median of $52.5 \%$.Net assets profit rate (Nebirate) referred to income before tax and provision for loan loss divided by the banks' net assets, the average of which is $31.31 \%$ and the median is $29.94 \%$.The average value of capital adequacy rate is $11.17 \%$, the median of which is $11.34 \%$.

\subsection{Empirical results}

\subsubsection{Unit root tests}

Table 2 presents the result of unit root tests, which gained by using Augmented Dickey-Fuller (ADF) method for unit root test. We found that Nebirate, LLP and LLA have a significant non-stationary feature, and the feature of Capitalrate is stable. Differences of the above variables are stable. Non-stationary variables which be used in static panel model would lead to correlation between explanatory variables and random error items. Non-consistence estimation for variables will rise when we estimate panel data using fixed effects or random effects will.

\subsubsection{Estimation for DLLP and NDLLP}

According to the above-mentioned characteristics of panel data, we adopted GMM model to estimate DLLP and NDLLP. GMM model was developed by Arellano and Bond (1991), Arellano and Bover (1995), Blundell and Bond (1998). Windmeijer (2005) estimated standard variance by using GMM two-step method to reduce small sample's estimated error. Table 3 shows dynamic panel estimating result, which reports that the correlation between the previous year's NPLrate and LLP is 0.0138, the significance of which is at the $5 \%$ level. The correlation between $\triangle N P L r a t e_{i, t}$ and $L L P$ is 0.0058 , significant at the $10 \%$ level. Wald Chi2 (5) is equal to 41.79 , which refers to the overall validation of 
the model (1).Table 4 reports the measuring values of $N D L P_{i, t}$, The average values of $N D L L P_{i, t}$ and $D L L P$ respectively are $0.7199 \%$ and $0.0153 \%$.

\subsubsection{GMM estimation}

Due to endogenous relationship among LLP, Loanrate, Capitalrate and Nebirate ,panel VAR estimation model can more effectively reflect the interactive influences. The aforementioned unit root test results show that $L L P$ 、 Loanrate 、Capitalrate and Nebirate apply to I (1) distribution, which indicating that there is long-term equilibrium relationship among these variables. According to SIC's information criterion, we could use first-order lag PVAR model to estimate. The GMM estimation results of PVAR is shown in Table 5 and Table 6.

Seen from table 5, the effects that all variables have on $D L L P$ are relatively small. The lagged one period $D L L P_{t-1}$ has effects on the current variable $D L L P$, the coefficience of which is 0.2815 , at the $5 \%$ significant level, which indicates that $D L L P$ has path dependent features. On the contrary, $D L L P_{t-1}$ has great significant effects on Loanrate, the coefficience of which is 2.2309 , at the $1 \%$ significant level, which indicates that when bank has enough DLLP, banks will have greater motivation to supply credit that caused loan further growth. Hyphosis 1 has been demonstrated.

The coefficience of $D L L P_{t-1}$ to Nebirate is 3.8253 at the $1 \%$ significant level, which indicates that when banks have enough DLLP, banks have sufficient motivation to conduct earnings management and have a good financial report. Hypothesis 2 can be verified. Meanwhile, the coffeicience of $D L L P_{i, t-1}$ to Capitalrate is-66.7449 at the $5 \%$ significant level. Loan loss provisions ( $L L P$ ) has a significant impact on the after-tax profits, which casuses the banks' capital adequacy rate decreasing. Table 6 reflects interactive relationship between $N D L L P \mathrm{~s}$ and various variables. From the table 6 , the effects between $N D L L P$ and other variables are relatively small. NDLLPi,t-1 has an effect on $N D L L P$, which illustrate that loan loss provisions are drawn based on bank 's non-performing loan rate of assets and have no significant 'cycle' impact on bank commercial credit. And the same as the effect of DLLP, the coefficient of NDLLP on capital adequacy rate is -432.0657 , at the $5 \%$ significant level. Hyphosis 3 has been demonstrated.

\subsubsection{Analyzing Panel Error Variance Decomposition}

(1) Error Term Description of DLLP and NDLLP: as shown in Table 7 and Table 8 : during the $10^{\text {th }}$ period, the explanatory power of Loanrate,Capitalrate and Nebirate for the error term of DLLP is very small. However, the explanatory power of Loanrate,Capitalrate and Nebirate for the error term of $N D L L P$ is respectively $8.5 \%, 3.1 \%$ and $2.9 \%$. which confirmed that there is long term influence relationship between $N D L L P$ and commercial credit, and performance and capital adequacy rate.

(2) Error Term Description of Loanrate: during the $10^{\text {th }}$ period, the explanatory power of NDLLP on the error term of Loanrate is 0.005; and the explanatory power of DLLP on the error term of Loanrate is 0.092, which illustrates that the greater bank's LLPs are, the greater speeds of credit supply are. From table 7 and 8, we could find that Nebirate has little impact on the error term of Loanrate, almost zero, which indicates the growth of profit is not driving factor to propel credit supply. Capitalrate has certain explanatory power on the error term of Loanrate as table 7 and table 8 showed, indicating that Capitalrate is an important factor required consideration in the process of credit growing .

(3) Error Term Analyzing of Nebirate: during the $10^{\text {th }}$ period, the explanatory power of NDLLP and DLLP on the the error term of Nebirate is relatively large, and is respectively $13.1 \%$, which indicates that that the bank always have motivation to conduct earnings management in the long run, based on the requirements of drawing LLPs. Table 7 and table 8 showed that Loanrate has a certain explanatory power on the Nebirate error term, Indicating that loan growth is important driver to propel the growth of bank's profit growing. On the contrary, the viewpoint couldn't be set up.

(4) Error Term Analyzing of Capitalrate: table 7 and table 8 showed that the explanatory power of Loanrate, Nebirate, NDLLP and DLLP on the error term of Capitalrate is relatively large, which is above the $9 \%$ level. There is great explanatory power of Loanrate on the error term of Capitalrate is 
more than 30\%, which indicates that loan growth will have significant effect on the capital adequacy rate.

\subsubsection{Analyzing Impulse Response Function}

Impulse response function reflects effect of a variable in the panel model orthogonal impact on the each variable in the system, which is the further test of the GMM estimation. Figure 1 shows DLLP's impulse response diagram. When Loanrate, Nebirate and Capitalrate has impulse from DLLP, there will be a significant response, and this response is not eliminated in the long run. Higher $D L L P$ will push Loanrate increasing and DLLP also contributed to profit growth of Nebirate, which indicates that the greater proportion of DLLP is , the greater growth of loan scale is. While the motivation for banks to improve their improve is also significant. DLLP has the negative impact on Capitalrate, which is declining over the continuing of time ,but couldn't eliminate to $6^{\text {th }}$ period.

Figure 2 shows impulse response diagram of $N D L L P$. As figure 2 showed, the impact of the NDLLP had no significant effect on Loanrate; the impact of the NDLLP have a positive effect on Nebirate and have a negative effect on Capitalrate. The effects of the impact gradually decay after the third period. Figure 1 and Figure 2 also show the interaction relationship among the profit indicators (Nebirate), loan rate (Loanrate) and capital adequacy rate (Capitalrate).

The impact of the Nebirate has no significant effect on Loanrate and has a negative effect on Capitalrate. which disappears during the second period. The result indicates that profit growth has not improved loan scale growth . At the initial stage, there is a negative relationship between profits and capital adequacy rate, which indicating that banks manage earning by drawing LLPs, but reducing the bank's capital adequacy rate. This conclusion could be further confirmed from the significant positive impulse of Loanrate to Nebirate, but significant negative impluse to Capitalrate.

\section{Conclusions and Policy Recommendations}

Owing to LLPs divided into DLLPs and NDLLPs, we could respectively identify the impact of LLPs on bank credits, banks performance and capital adequacy rate, which could verify the objectives of LLPs, that is for requirements of earning management or capital regulatory. At the same time, we could verify whether LLPs are "cyclical characteristic" or not . From GMM estimation, error decomposition analyzing and impulse response analyzing, we could see $D L L P$ has significant effect on bank credits, which lasts a long time. The conclusions confirmed that there is no "procyclical" feature for LLPs. The reason is that banks often draw excessive provisions which provide a basis for banks to expand credit scale, and make loan growth keep pace with LLPs. From the results of panel VAR model, we could find that DLLPs and Nebirates have a significant positive relationship, which indicating that banks have obvious motivation to conduct earning management and expand DLLPs. The conclusion is consistent with LLPs' countercyclical features, which illustrates that banks draw much more LLPs to prepare for the economy recession. There is a significant inverse relationship between DLLP and Capitalrate, so does NDLLP, which is not comply with capital regulating hypothesis. The result of above examination indicates that banks have not effectively conduct capital regulating for the objective of capital adequacy rate. The reason is that since 2005, China's economy has been growing rapidly and banks' profits have also been increasing greatly. Therefore, banks have confidence to meet the objectives of capital adequacy rate and don't need to use LLPs for regulating capital[26,27,28].

By using panel VAR test, we could confirm that LLPs of listed banks in China have "countercyclical" features. The results illustrate that listed banks make use of LLPs to manage earnings, on the other hand, higher DLLPs have significant negative impacts on capital adequacy rate. Although China's commercial banks' capital adequacy rate is $11.17 \%$ on average , considering earning management. It is possible that capital adequacy rate could be downward with

China's economic's growing rate being slow.

This paper provides valuable policy implication for drawing LLPs. Although many national countries have recommended the forward-looking method for LLPs. We should pay more attention suitability of the method in China. China's accounting system at the implementation level also needs to be perfected, especially there are many problems in the respects of corporate governance and internal 
control systems, which is closely connected with the implementation of accounting system. Forward looking method being adopted hastily provides sensible reasons for earning management. While excessive earning management could undermine the bank's capital basis and decrease capital adequacy rate ,which is not contribute to bank's long-term and sustainable development.

\section{Reference}

[1] Asokan Anandarajan - Iftekhar Hasan -Cornelia McCarthy. 2006, The use of loan loss provisions for capital management, earnings management and signalling by Australian banks Bank of Finland Research Discussion Papers 23

[2] Ahmed, A. S., Takeda, C., Thomas, S., 1999. Bank loan loss provisions: a re-examination of capital manage- ment, earnings management and signaling eaects. Journal of Accounting and Economics, 28, 1-26.

[3] Anne Beatty Scott Liao .Regulatory Capital Ratios, Loan Loss Provisioning and Pro-cyclicality October 15, 2009

[4] Arellano, M., Bond, S.R., 1991. Some Tests of Speci.cation for Panel Data: Monte Carlo Evidence and an Application to Employment Equations. Review of Economic Studies, 58, 277-297. [4] Arellano, M., Bover, O., 1995. Another Look at the Instrumental Variables Estimation of Error-components Models. Journal of Econometrics, 68, 29-51.

[5] Beatty, A., and S. Liao. 2011. Do Delays in Expected Loss Recognition Affect Banks' Willingness to Lend? Journal of Accounting \& Economics 52 (1): 1-20

[6] Bernanke, B. and C. Lown, 1991. The Credit Crunch. Brookings Papers on Economic Activity 2, 205-247.

[7] Borio, C., Fur.ne, C., Lowe, P., 2001. Procyclicality of the financial system and .financial stability: issues and policy options. BIS Papers 1.

[8]Duan Junshan, Zhou Xinyue and Zou weiwei . Loan ,Earning Management and Dynamic Adjustment of Loan Loss Provisions. Financial Review . 2011（5） . pp31-36

[9]Duan Junshan, Analyzing Influencing Factors for Drawing Loan Loss Provisions _based on listed commercial banks dynamic panel appraise. ShanHai Finance. 2012 (5) , pp36-40.

[10]Handorf, W. and L. Zhu, 2006. US Bank Loan-Loss Provisions, Economic Conditions, and Regulatory Guidance. Journal of Applied Finance April, 97-114

[11]LI Yujia , LU Jun. Loan loss provision , Capital Regulating and Banks Performance.

Contemporary Economic Science. 2009 (10) , pp31-38

[12] LI Yujia , LU Jun , CHEN Qianli. Loan Loss Provisioning and Credit Decrease, Contemporary Economic Science. 2007 (9) , pp56-64.

[13]LI Yujia and LU Jun. Loan Loss Provisioning and Capital Adequacy Rate Regulating _from Japanese banks panel data. International Financial Research. 2008(5), pp43-50.

[14]LI Yujia and LU Jun. Risk Premium , Anticipated Loss and Anticipated Loan Loss provisions. Contemporary Finance . 2007(12).

[15]Kishan, R, and T. Opiela, 2000. Bank Size, Bank Capital, and the Bank Lending Channel. Journal of Money, Credit and Banking 32, 121-141

[16] McNichols, M., and G.P. Wilson, 1988. Evidence of earnings management from the provision for bad debts. Journal of Accounting Research, 26(3): 1-31.

[17]John C. Dugan, Comptroller of the Currency, the Institute of International Bankers made on March 2, 2009 entitled "Loan Loss Provisioning and Pro-cyclicality"

[18] Peek, J., Rosengren, E.S. 1995. Bank regulation and credit crunch. Journal of Banking and Finance, 19, 679-692.

[19]Sun Lianyou. Dynamic Loan Loss Provisions Policy and Application . International Financial Research. 2004(12), pp 24-27

[20]Sun Tianqi and Yanglan. Investiagation about the Implementation of Loan Loss Provisions -based on five listed banks. Financial Research. 2009 (6) pp116-130

[21] Shrieves, R.E., Dahl, D., 2002. Discretionary accounting and the behavior of Japanese banks under financial distress. Journal of banking and finance, 27(7), 1219-1243. 
[22] Vincent BOUVATIER Laetitia LEPETIT (2006) Banks’ procyclicality behavior!: does provisioning matter!? Maison des Sciences Économiques, 106-112 boulevard de L'Hôpital, 75647 Paris Cedex 13

http://mse.univ-paris1.fr/Publicat.htm ISSN : 1624-0340

[23]Vyas, D. 2011. The Timeliness of Accounting Write-downs during the Recent Financial Crisis, Journal of Accounting Research, 49 (3): 823-860.

[24] Robert M. Bushman and Christopher D. Williams: Delayed Expected Loss Recognition and the Risk Profile of Banks, First Draft: October 15, 2011 Kenan-Flagler Business School University of North Carolina-Chapel Hill

[25]Xu You chuan, Liu Qinfu and Wang ZhiXin . Appropriateness of Loan Loss Provisions based on Dynamic and Forward-looking methods. Financial Research. 2011（12）pp100-114

[26]B. Wu and H. Shen, Analyzing and Predicting News Popularity on

Twitter, International Journal of Information Management Corresponding, Vol. 35 (6), pp. 702-711, 2015

[27]B. Wu and H. Shen, Mining Connected Global and Local Dense SubGraphs for BigData, International Journal of Modern Physics C, Issue: 27, article ID:1650072, 2016 [28]Wu, B., \& Shen, H. (2017). Exploiting Efficient Densest Subgraph Discovering Methods for BigData. IEEE Transactions on Big Data. 